\title{
Article \\ Challenges in the Highly Selective [3 + 1]-Cycloaddition of an Enoldiazoacetamide to Form a Donor-Acceptor Cis-Cyclobutenecarboxamide ${ }^{\dagger}$
}

\author{
Sipak Joyasawal (1), Donghui Ma and Michael P. Doyle *(i) \\ Department of Chemistry, The University of Texas at San Antonio One UTSA Circle, San Antonio, TX 78249, USA; \\ sipak.joyasawal@utsa.edu (S.J.); ma698@purdue.edu (D.M.) \\ * Correspondence: michael.doyle@UTSA.edu \\ + Dedicated to Albert Padwa for his contributions to chemistry.
}

Citation: Joyasawal, S.; Ma, D.;

Doyle, M.P. Challenges in the Highly Selective [3 + 1]-Cycloaddition of an Enoldiazoacetamide to Form a Donor-Acceptor Cis-Cyclobutenecarboxamide. Molecules 2021, 26, 3520. https:// doi.org/10.3390/molecules26123520

Academic Editor: Fawaz Aldabbagh

Received: 16 May 2021

Accepted: 31 May 2021

Published: 9 June 2021

Publisher's Note: MDPI stays neutral with regard to jurisdictional claims in published maps and institutional affiliations.

Copyright: (c) 2021 by the authors. Licensee MDPI, Basel, Switzerland. This article is an open access article distributed under the terms and conditions of the Creative Commons Attribution (CC BY) license (https:// creativecommons.org/licenses/by/ $4.0 /)$.

\begin{abstract}
A substituted donor-acceptor cyclobutenecarboxamide is synthesized with modest enantiocontrol through a chiral copper(I) complex catalyzed [3+1]-cycloaddition reaction of $\alpha$-acyl diphenylsulfur ylides with 3-siloxy-2-diazo-3-butenamides. With a methyl substituent on the 4position of the 3-butenamide, the cis-vicinal-3,4-disubstituted cyclobutenecarboxamide is formed with >20:1 diastereocontrol. Donor-acceptor 3-methyl-2-siloxycyclopropenecarboxamide is rapidly formed from the reactant enoldiazoamide and undergoes catalytic ring opening to give only the $Z$ - $\gamma$-substituted metallo-enolcarbene. Elimination from 3-siloxy-2-diazo-3-pentenamide to form the conjugated 3-siloxy-2,4-pentadienamide is competitive but minimized at low temperature.
\end{abstract}

Keywords: donor-acceptor cyclobutenecarboxamide; [3 + 1]-cycloaddition reaction; 3-siloxy-2-diazo3-butenamides; Z- $\gamma$-substituted metallo-enolcarbene; box ligands; copper(I)

\section{Introduction}

The four-membered carbon ring is an important structural framework present in natural products and biologically active compounds, but is less accessible than are other ring structures [1-3]. Furthermore, cyclobutanes and cyclobutenes are integral to synthetic strategies involving facile ring-expansion or ring-cleavage reactions [4,5]. The synthesis of cyclobutenes is normally relegated to [2 + 2]-cycloaddition reactions between alkynes and activated alkenes [6-15], and diastereocontrol for the synthesis of 3,4-disubstituted cyclobutenes is controlled by the geometrical isomerism of the reactant alkyne. Until recently [16,17], however, there were no examples of a broadly applicable enantioselective version of this [2 +2$]$-cycloaddition process. Diastereocontrol is conveniently established by the alkene reactant with this methodology; enantiocontrol is the challenge (Figure 1a).

Previous research from our laboratory established that catalytic [3+1]-cycloaddition of silyl group-protected enoldiazoacetate esters with $\alpha$-acyl dimethylsulfur ylides was effective in forming stable donor-acceptor cyclobutene derivatives (Figure 1b) [18]. This methodology produced 1,2,4-trisubstituted $\left(\mathrm{R}^{1}=\mathrm{H}\right)$ 2-siloxycyclobutenecarboxylates in good yields with uniformly high enantiocontrol. Diastereoselectivity for the formation of 1,2,3,4-tetrasubstituted $\left(\mathrm{R}^{1}=\mathrm{Me}\right)$ 2-siloxycyclobutenecarboxylates was good $(>10: 1)$ to excellent (>20:1) with the trans isomer dominant; however, even in this earlier study there were indications that formation of the cis-diastereomer could be competitive.

Prior research has suggested that diazoamides are more stable and more selective in their catalytic reactions emanating from metal carbene intermediates $[19,20]$, and we anticipated that this selectivity could be applied to catalytic [ $3+1]$-cycloaddition of silyl group protected enoldiazoacetamides. However, initial efforts indicated that the same conditions and catalysts that were effective with enoldiazoacetates were not as productive or selective with enoldiazoacetamides. In particular, reactions with $\alpha$-acyl dimethylsulfur 
ylides gave low yields for the cycloaddition product, and stereoselectivities were low. To enhance both the efficiency of the transformation and its selectivity to produce substituted donor-acceptor cyclobutenecarboxamides with exceptional stereocontrol, we undertook a comprehensive effort to optimize reactants, conditions, and catalyst ligands to achieve high yields, as well as high enantioselectivities and diastereocontrol (Figure 1c).

a. [2+2]-Cycloaddition reactions for stereoselective synthesis of cyclobutenes

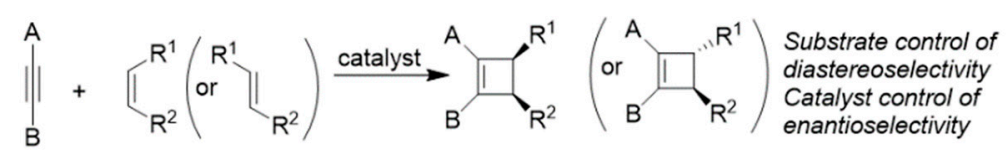

b. $[3+1]$-Cycloaddition reactions of enoldiazoacetates with acyl dimethylsulfur ylides ${ }^{18}$

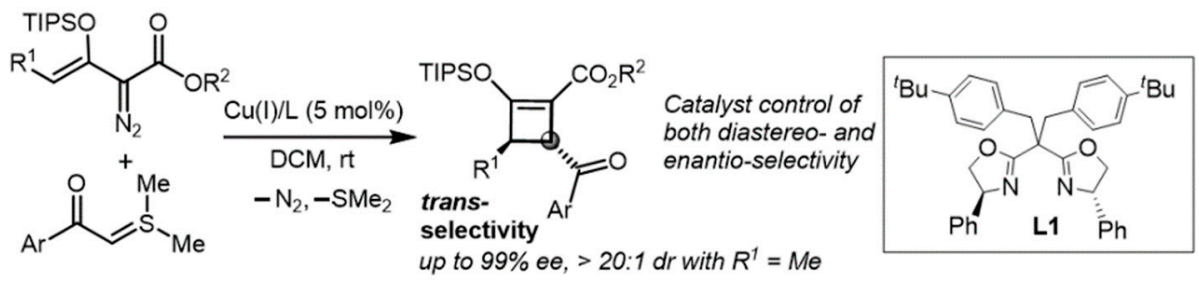

c. [3+1]-Cycloaddition reactions of enoldiazoacetamides with acyl diphenylsulfur ylides (This work)

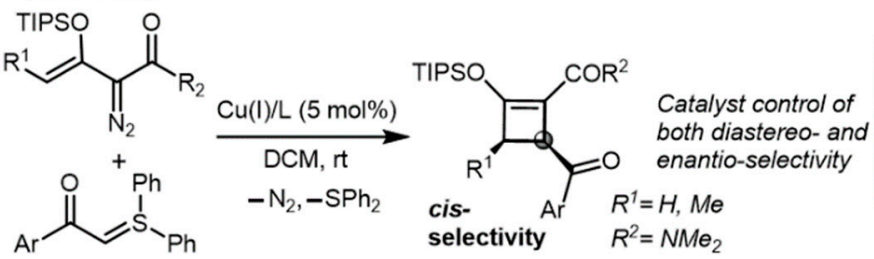

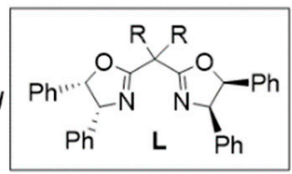

selectivity $\quad R^{2}=\mathrm{NMe}_{2}$

Figure 1. Cycloaddition reactions that form cyclobutene derivatives: (a) $[2+2]$-cycloaddition; (b) $[3+1]$-cycloaddition of silyl group-protected enoldiazoacetate esters; (c) [3+1]-cycloaddition of silyl group-protected enoldiazoacetamides (this work).

\section{Results and Discussion}

We began our investigation with the cycloaddition of TIPS-protected $\mathrm{N}, \mathrm{N}$-dimethylenoldiazoacetamide 1a with $\alpha$-benzoyl dimethylsulfur ylide 2a using the same copper(I) catalyst and chiral ligand (L1, Scheme 1) that were most effective in reactions with enoldiazoacetates (Figure 2) [18]. However, reaction at room temperature under the same conditions produced the $[3+1]$-cycloaddition product $3 \mathbf{a}$ in $58 \%$ yield having $0 \%$ ee after complete dinitrogen extrusion of 1a (Table 1, entry 1). Since phenyl in place of methyl increases the reactivity of the sulfur ylide [21], $\alpha$-benzoyl diphenylsulfur ylide $\mathbf{2 b}$ was prepared [22-25], and its reaction with 1a under the same conditions gave $3 \mathbf{a}$ in $85 \%$ yield with $17 \%$ ee (Table S1, entry 2, Supplementary Materials). The major enantiomer was assigned to be $R$ based on its correlation in sign of rotation and relative retention volume by HPLC compared with the [3+1]-cycloaddition product with the corresponding enoldiazoacetate [18]. 
<smiles>CC(C)(C)c1ccc(CC(Cc2ccc(C(C)(C)C)cc2)(C2=NC(c3ccccc3)CO2)C2=NC(c3ccccc3)CO2)cc1</smiles><smiles>[R]C([R])(C1=N[C@@H](c2ccccc2)[C@H](c2ccccc2)O1)c1coc(-c2ccccc2)n1</smiles>

L12, $R=M e$

$\mathrm{L} 13, \mathrm{R}=\mathrm{Bn}$

L14, R, R = Cyclopentyl

L15, $R=$ 2,4,6-trimethylBn

L16, $R=4-^{-} \mathrm{BuBn}$
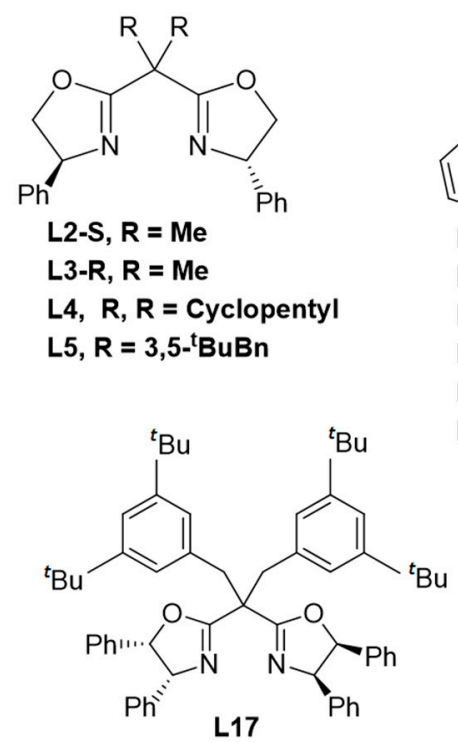

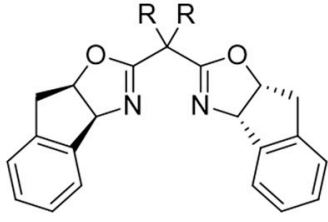

L6, $\mathrm{R}=\mathrm{Bn}$

L7-SR, R $=3,5-^{\mathrm{t}} \mathrm{BuBn}$

L8-RS, R = 3,5-' ${ }^{\mathrm{B} u B n}$

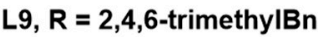

L10, R,R = Cyclobutyl

L11, R, R = Cyclopentyl

Scheme 1. Ligands employed in the search for enantioselectivity in the $[3+1]$-cycloaddition reactions of enoldiazoacetamide 1a.

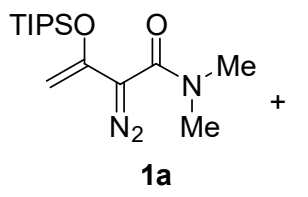<smiles>[R][SH]([R])=CC(=O)c1ccccc1</smiles>

2b, $R=P h$
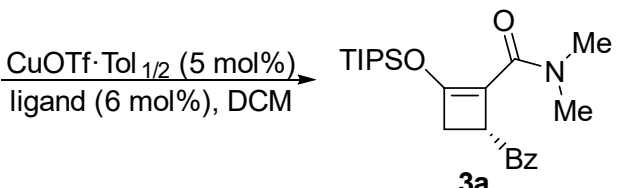

$3 a$

Figure 2. $[3+1]$-cycloaddition reactions with enoldiazoamide 1a.

\subsection{Ligand Control of Enantioselectivity in the [3+1]-Cycloaddition of 2-Diazo-N,N-dimethyl-3-(triisopropylsiloxy)but-3-enamide}

Using the 4-phenyl-Sabox L1, the ester analog of 1a, methyl enoldiazoacetate, was able to reach $83 \%$ ee in its [3+1]-cycloaddition reaction with $\mathbf{2 b}$. That $17 \%$ ee (Table S1, entry 2) could be achieved in reactions with $N, N$-dimethyl-enoldiazoacetamide 1a was surprising and not easily explained as due to the size of dimethylamido relative to methoxy groups, nor by the expected electronic influence of amide relative to ester groups on the diazo carbon. Consequently, we directed our attention to expanding our search for ligands that might increase enantioselectivity with a survey of Box (bis-oxazoline) and SaBox (sidearmed bis-oxazoline) ligands (Scheme 1).

To determine the ability of ligands to enhance enantiocontrol in the $[3+1]$-cycloaddition reactions of $N, N$-dimethyl-enoldiazoacetamide $\mathbf{1 a}$ with ylides $\mathbf{2} \mathbf{a}$ or $\mathbf{2} \mathbf{b}$ using $\mathrm{CuOTf} \cdot \mathrm{Tol}_{1 / 2}$, the series of Box and Sabox ligands (L2-L17 in Scheme 1) were screened (Table 1 and Supplementary Materials). Low enantioselectivities ( $5 \%$ ee) and product yields were achieved in copper(I) catalyzed reactions with the dimethylsulfur ylide 2a using L3, L12, and L17 (55-60\% yield, 5\% ee, Table S1, entries 5, 12, 18). However, changing to the $\alpha$-benzoyl diphenylsulfur ylide (2b) brought about an increase in enantioselectivity (34\% ee) using Box L2 (Table S1, entry 3), which was greater than that with Sabox L1, but Sabox L5 (Table 1, entry 2) with the 3,5-di-tert-butylbenzyl sidearm gave a near doubling in \% ee. Use of indanyl Sabox ligands L6-L8 (Table S1, entries 7, 8, 9) were disappointing with ee's less than 15\%, but L9, and L10 provided modest enantiocontrol (Table 1, entries 3, 4). Only with the cis-3,4-diphenyl Sabox ligands did enantiocontrol reach beyond $60 \%$ ee, and L17 (Table 1, entry 10) was designated to be the optimum ligand. Lowering the temperature increased the ee by $4 \%$ for each 20 -degree decrease (Table 1, entries 10, 11, 12). The use of $\mathrm{CuBF}_{4}\left(\mathrm{CH}_{3} \mathrm{CN}\right)_{4}$ in place of $\mathrm{CuOTf} \cdot \mathrm{Tol}_{1 / 2}$ had no meaningful influence on $\%$ yield or enantioselectivity (Table 1 , entries $13,14,15$ ). Use of alternative solvents, including 
DCE, toluene, and ethyl ether, with L17 led to much lower \% ee values (see Supplementary Materials, Scheme S1, Table S2).

Table 1. Optimization for Catalytic Asymmetric [3+1]-Cycloaddition Reaction of $\mathbf{1 a}$ with $\mathbf{2 a} / \mathbf{2} \mathbf{b}$ a .

\begin{tabular}{|c|c|c|c|c|c|c|c|}
\hline Entry $^{a}$ & Catalyst & Ligand & Ylide & $t / h$ & $\mathrm{~T} /{ }^{\circ} \mathrm{C}$ & Yield [\%] ${ }^{b}$ & ee $[\%]^{\mathrm{c}}$ \\
\hline 1 & CuOTf $\cdot$ Tol $_{1 / 2}$ & L1 & $2 a$ & 18 & $\mathrm{rt}$ & 58 & 0 \\
\hline 2 & CuOTf $\cdot$ Tol $_{1 / 2}$ & L5 & $2 b$ & 24 & rt & 74 & 64 \\
\hline 3 & $\mathrm{CuOTf} \cdot \mathrm{Tol}_{1 / 2}$ & L9 & $2 b$ & 16 & $\mathrm{rt}$ & 71 & 32 \\
\hline 4 & CuOTf $\cdot$ Tol $_{1 / 2}$ & L10 & $2 b$ & 16 & $\mathrm{rt}$ & 76 & 45 \\
\hline 5 & CuOTf $\cdot$ Tol $_{1 / 2}$ & L12 & $2 b$ & 16 & $\mathrm{rt}$ & 90 & 38 \\
\hline 6 & CuOTf $\cdot$ Tol $_{1 / 2}$ & L13 & $2 b$ & 16 & $\mathrm{rt}$ & 78 & 44 \\
\hline 7 & CuOTf $\cdot$ Tol $_{1 / 2}$ & L14 & $2 b$ & 16 & $\mathrm{rt}$ & 54 & 34 \\
\hline 8 & $\mathrm{CuOTf} \cdot \mathrm{Tol}_{1 / 2}$ & L14 & $2 b$ & 24 & 0 & 60 & 38 \\
\hline 9 & CuOTf $\cdot$ Tol $_{1 / 2}$ & L16 & $2 b$ & 24 & $\mathrm{rt}$ & 80 & 58 \\
\hline 10 & $\mathrm{CuOTf} \cdot \mathrm{Tol}_{1 / 2}$ & L17 & $2 b$ & 16 & $\mathrm{rt}$ & 79 & 60 \\
\hline 11 & CuOTf $\cdot$ Tol $_{1 / 2}$ & L17 & $2 b$ & 24 & 0 & 82 & 64 \\
\hline $12^{\mathrm{d}}$ & $\mathrm{CuOTf} \cdot \mathrm{Tol}_{1 / 2}$ & L17 & $2 b$ & 24 & -20 & 74 & 68 \\
\hline 13 & $\mathrm{CuBF}_{4}\left(\mathrm{CH}_{3} \mathrm{CN}\right)_{4}$ & L17 & $2 b$ & 16 & $\mathrm{rt}$ & 79 & 59 \\
\hline 14 & $\mathrm{CuBF}_{4}\left(\mathrm{CH}_{3} \mathrm{CN}\right)_{4}$ & L17 & $2 b$ & 16 & 0 & 75 & 65 \\
\hline $15^{\mathrm{d}}$ & $\mathrm{CuBF}_{4}\left(\mathrm{CH}_{3} \mathrm{CN}\right)_{4}$ & L17 & $2 b$ & 24 & -20 & 82 & 67 \\
\hline
\end{tabular}

a Unless otherwise noted, the reactions were performed as follows: a solution of CuOTf. Tol ${ }_{1 / 2}(0.01 \mathrm{mmol}$ $5 \mathrm{~mol} \%)$, and ligand $(0.012 \mathrm{mmol}, 6 \mathrm{~mol} \%)$ in dry DCM $(1.0 \mathrm{~mL})$ under $\mathrm{N}_{2}$ was stirred at $\mathrm{rt}$ for $1 \mathrm{~h}$, after which sulfur ylide $\mathbf{2 a}$ or $\mathbf{2 b}(0.20 \mathrm{mmol})$ in dry DCM $(0.5 \mathrm{~mL})$ and $\mathbf{1 a}(0.24 \mathrm{mmol})$ in dry DCM $(0.5 \mathrm{~mL})$ were added at the specified temperature. The reaction solution was stirred at the same temperature for the indicated time. ${ }^{b}$ Isolated yield. ${ }^{c}$ Enantiomeric excess was determined by HPLC analysis on a Chiralpak OD-H column. Negative values specify the opposite enantiomer. ${ }^{\mathrm{d}}$ Reactions at $-20^{\circ} \mathrm{C}$ were performed in a freezer.

\subsection{Ligand Control of Diastereoselectivity and Enantioselectivity in the [3+1]-Cycloaddition of 2-Diazo-N,N-dimethyl-3-(triisopropylsiloxy)pent-3-enamide}

With moderate enantioselectivity in place for the [3+1]-cycloaddition of $\mathrm{N}, \mathrm{N}$-dimethylenoldiazoacetamide $\mathbf{1} \mathbf{a}$ with $\alpha$-benzoyl diphenylsulfur ylide $\mathbf{2} \mathbf{b}$, our next goal was controlling diastereoselectivity. Use of the $\gamma$-methyl-substituted $\mathbf{1 b}$ was anticipated to result in the formation of vicinal 3,4-disubstituted donor-acceptor cyclobutene $3 \mathbf{b}$ which can be produced as either the cis $(\mathbf{Z}-\mathbf{3 b})$ or trans $(\boldsymbol{E}-\mathbf{3} \mathbf{b})$ diastereomer [26-29]. Prior results from the corresponding $\gamma$-methyl-enoldiazoacetate showed a substantial increase in enantioselectivity (to $95 \%$ ee) over reactions with the enoldiazoacetate without $\gamma$-substitution $(83 \%$ ee), but a reduction in the $\mathrm{dr}$ (diastereomeric ratio) from $t: c>20: 1$ with $2 \mathbf{a}$ to $t: c=13: 1$ with $\mathbf{2 b}$ [18] so we anticipated an increase in enantioselectivity but a further decrease in the $t: c$ ratio in reactions of $\mathbf{1 b}$ with $\mathbf{2 b}$. $\gamma$-Methyl-substituted $\mathbf{1 b}$ prepared by TIPS transfer from TIPSOTf to the precursor $\alpha$-diazo- $\beta$-ketoacetamide promoted by triethylamine yielded $\mathbf{1 b}$ (Scheme 2) having a 3:1 E:Z ratio [30]; the expected [3 + 1]-cycloaddition reaction with this stereomeric mixture catalyzed by CuOTf $\cdot \mathrm{Tol}_{1 / 2} / \mathbf{L} \mathbf{1 7}$ produced both $\mathbf{Z}-\mathbf{3 b}$ and $\mathbf{E}-\mathbf{3 b}$ in a 7:1 ratio (Table S3, entry 1, Supplementary Materials) for a reversal in diastereocontrol but in low yield (35\%), so we surveyed ligands again and found that $\mathbf{L 1 4}$ gave the highest yield of $Z-3 \mathbf{b}(57 \%)$ with a $Z / E-3 \mathbf{b}$ ratio of 6 ( $64 \%$ ee):1(7\% ee) along with the surprising production of diene 4 (22\% yield) for an overall yield of $89 \%$ (Scheme 3). Recognizing that the individual isomers of $\mathbf{1 b}$ could be acting differently in this catalytic reaction, we prepared Z-1b (25:1 Z:E, Scheme 4) [30] and subjected this diazo compound to the same reaction conditions and found both $Z-3 \mathbf{b}$ and $E-3 \mathbf{b}$ in a $9: 1$ ratio $(77 \%$ yield with $68 \%$ ee for $Z-3 \mathbf{b}$ and $20 \%$ ee for $\boldsymbol{E}-3 \mathbf{b}$ ), along with $\mathbf{4}$ (15\% yield). Since the donor-acceptor cyclopropene formed from the reactant enoldiazoacetamide $\mathbf{1 b}$ could be the resting state for the intermediate metallo-enolcarbene [31], we prepared cyclopropene 5 (Scheme 5) [32] and subjected this compound to the same reaction conditions to find both $Z-3 \mathbf{b}$ and $E-3 \mathbf{b}$ in a $12: 1$ ratio $(73 \%$ yield with $71 \%$ ee for $Z-3 b$ and $16 \%$ ee for $E-3 b)$, along with 4 ( $8 \%$ yield). The same reaction performed at $-20{ }^{\circ} \mathrm{C}$ showed much higher selectivity overall (Scheme 3), with an impressive 24:1 Z-3b:E-3b ratio and 79\% ee for the cis diastereoisomer, and significantly less diene (Scheme 3 ). 


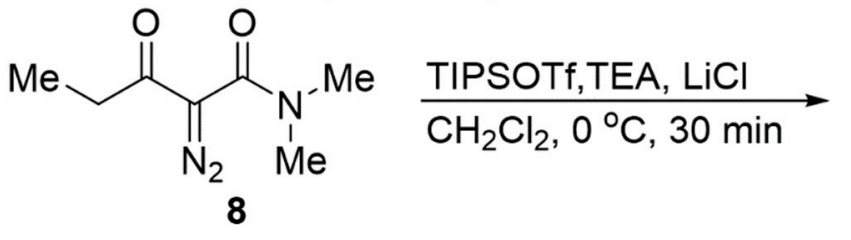<smiles>C/C=C(\OC(F)(F)F)C(=N)C(=O)N(C)C</smiles>

$Z: E-1 b=1: 3$

Scheme 2. Preparation of 2-Diazo- $N, N$-dimethyl-3-((triisopropylsiloxy)pent-3-enamide, $\mathbf{1 b}$ $(Z: E-1 b=1: 3)$.

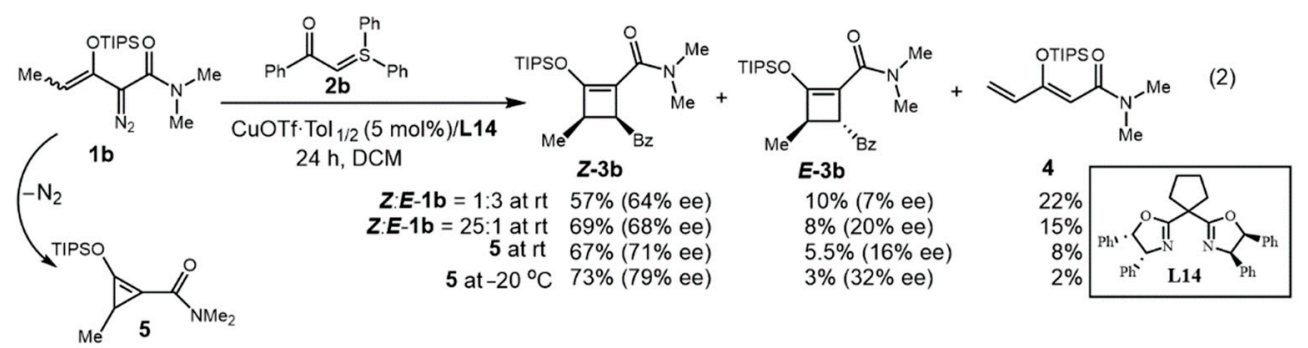

Scheme 3. Diastereoselectivity and enantioselectivity in [3+1]-cycloaddition reactions with $\gamma$-methyl enoldiazoamide $\mathbf{1 b}$.

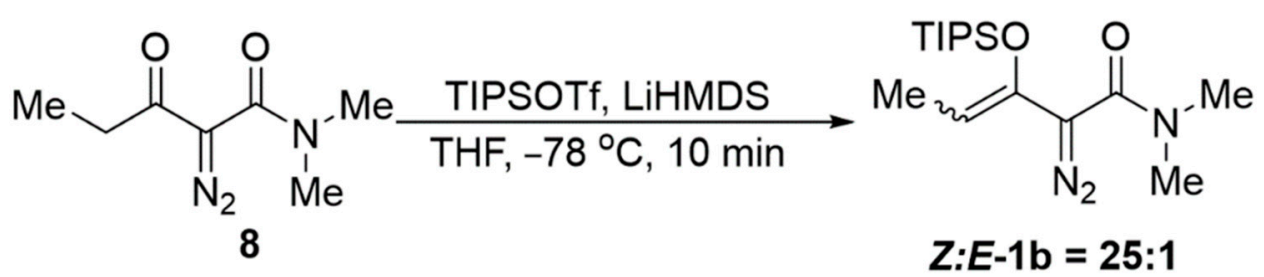

Scheme 4. Preparation of 2-Diazo- $N, N$-dimethyl-3-(triisopropylsiloxy)pent-3-enamide, $\mathbf{1 b}(\mathbf{Z}: \mathbf{E}-\mathbf{1 b}=\mathbf{2 5 : 1})$.<smiles></smiles>

$$
\begin{aligned}
& Z: E-1 b=1: 3 \\
& Z: E-1 b=25: 1
\end{aligned}
$$

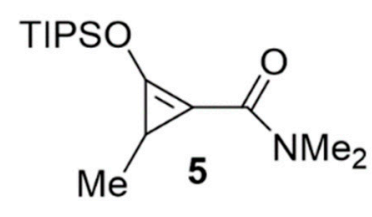

Scheme 5. Preparation of N,N,3-Trimethyl-2-(triisopropylsiloxy)cycloprop-1-ene-1-carboxamide (5).

\subsection{Ligand Control of Enantioselectivity in the [3+1]-Cycloaddition of}

2-Diazo-N,N-dimethyl-3-methyl-2-(triisopropylsiloxy)-1-cyclopropenecarboxamide

The discovery that there was such a substantial reverse in diastereoselectivity in reactions performed with the enoldiazoacetamide (1) from that found with the corresponding enoldiazoacetate was surprising and prompted investigation of the effect of the ligand $\mathbf{L}$ on diastereocontrol. To avoid perturbations in selectivities arising from the different reactivities and selectivities of $\boldsymbol{E}$ - and $\mathbf{Z}-\mathbf{1 b}$, we chose to use donor-acceptor cyclopropene $\mathbf{5}$ as the carbene source. Previous results have shown that the donor-acceptor cyclopropene undergoes ring opening with transition metal catalysts to form only the Z-metallo-enolcarbene isomer [31]. We surveyed a representative series of Box and Sabox ligands for [3 +1$]-$ cycloaddition with $\mathbf{2 b}$, and these results are given in Table 2. As previously stated, yields of $[3+1]$-cycloaddition products are limited by the competing formation of diene 4 . However, even with this limitation, L14 (Table 2, entry 6) produced Z-3b with a 12:1 Z:E ratio at room temperature and allowed the isolation of pure $Z-3 b$ in $67 \%$ yield with $71 \%$ ee, and a higher yield, $\mathrm{dr}$ and \% ee were achieved when the reaction was performed at $-20{ }^{\circ} \mathrm{C}$ (Table 2 , entry 7). 
Table 2. Ligands screening for Catalytic Asymmetric [3+1]-Cycloaddition Reaction of donor acceptor cyclopropene 5 with $2 \mathbf{b}^{\text {a }}$.

\begin{tabular}{|c|c|c|c|c|c|c|c|c|}
\hline Entry $^{a}$ & Ligand & Solvent & $\mathrm{T} /{ }^{\circ} \mathrm{C}$ & $t / h$ & $\mathrm{dr}(Z: E)^{b}$ & Yield (ee) of $Z-3 b^{c}$ & Yield (ee) of $E-3 b^{d}$ & Yield (4) ${ }^{e}$ \\
\hline 1 & L1 & DCM & $\mathrm{rt}$ & 38 & $(2: 1)$ & $32 \%(-12 \%)$ & $12 \%(65 \%)$ & $47 \%$ \\
\hline 2 & L4 & DCM & $\mathrm{rt}$ & 24 & $(2.5: 1)$ & $50 \%(0 \%)$ & $18 \%(0 \%)$ & $4 \%$ \\
\hline 3 & L5 & DCM & $\mathrm{rt}$ & 24 & $(8: 1)$ & $28 \%(-69 \%)$ & $3 \%(62 \%)$ & $59 \%$ \\
\hline 4 & L11 & DCM & $\mathrm{rt}$ & 24 & $(5: 1)$ & $40 \%(62 \%)$ & $8 \%(56 \%)$ & $44 \%$ \\
\hline 5 & L12 & DCM & $\mathrm{rt}$ & 24 & $(5: 1)$ & $61 \%(48 \%)$ & $12 \%(10 \%)$ & $16 \%$ \\
\hline 6 & L14 & DCM & $\mathrm{rt}$ & 24 & $(12: 1)$ & $67 \%(71 \%)$ & $5.5 \%(16 \%)$ & $8 \%$ \\
\hline $7^{f}$ & L14 & DCM & -20 & 48 & $(24: 1)$ & $73 \%(79 \%)$ & $3 \%(32 \%)$ & $2 \%$ \\
\hline 8 & L16 & DCM & $\mathrm{rt}$ & 38 & $(10: 1)$ & $57 \%(59 \%)$ & $6 \%$ (NA) & $22 \%$ \\
\hline 9 & L17 & DCM & rt & 24 & $(18: 1)$ & $24 \%(63 \%)$ & $2 \%$ (NA) & $51 \%$ \\
\hline
\end{tabular}

${ }^{a}$ Unless otherwise noted, reactions were performed as follows: a solution of $\mathrm{CuOTf} \cdot \mathrm{Tol}_{1 / 2}(0.01 \mathrm{mmol}, 5 \mathrm{~mol} \%)$, and ligand $\mathbf{L}(0.012 \mathrm{mmol}$, $6 \mathrm{~mol} \%)$ in dry DCM $(1.0 \mathrm{~mL})$ under $\mathrm{N}_{2}$ was stirred at $\mathrm{rt}$ for $1 \mathrm{~h}$, after which sulfur ylide $2 \mathbf{b}(0.20 \mathrm{mmol})$ in dry DCM $(0.5 \mathrm{~mL})$ was added. Then cyclopropene $5(0.24 \mathrm{mmol})$ in dry DCM $(0.5 \mathrm{~mL})$ was added dropwise at the specific temperature, and the reaction solution was stirred at the same temperature for the indicated time. ${ }^{b} \mathrm{dr}$ calculated from the reaction mixture after completion of the reaction. ${ }^{\mathrm{c}}$ Isolated yield. ${ }^{\mathrm{d}}$ Yield of the E diastereomer was calculated from the ${ }^{1} \mathrm{H}$ NMR analysis of the reaction mixture. ${ }^{\mathrm{e}}$ Enantiomeric excess was determined by HPLC analysis on a Chiralpak OD-H column. ${ }^{\mathrm{f}}$ Reaction at $-20{ }^{\circ} \mathrm{C}$ was performed in a freezer.

\section{Materials and Methods}

\subsection{General Information}

All reactions, unless noted, were performed in oven-dried $\left(120^{\circ} \mathrm{C}\right)$ glassware with magnetic stirring under an inert atmosphere of dry nitrogen. Analytical thin layer chromatography was carried out using EM Science silica gel 60 F254 plates (MilliporeSigma, Burlington, MA, USA); visualization was accomplished with UV light (254 nm). Column chromatography was performed on CombiFlash ${ }^{\circledR}$ Rf200 and Rf+ purification systems (Teledyne Technologies, Thousand Oaks, CA, USA) using normal phase disposable columns. ${ }^{1} \mathrm{H}-\mathrm{NMR}$ spectra were recorded on a Bruker spectrometer $(500 \mathrm{MHz}$, Bruker Corporation, Billerica, MA, USA). Chemical shifts were reported in ppm downfield from tetramethylsilane with the solvent resonance as the internal standard $\left(\mathrm{CDCl}_{3}, \delta=7.28\right)$. Spectra were reported as follows: chemical shift $(\delta \mathrm{ppm})$, multiplicity $(\mathrm{br}=$ broad singlet, $\mathrm{s}=$ singlet, $\mathrm{d}=$ doublet, $\mathrm{t}=$ triplet, $\mathrm{q}=$ quartet, $\mathrm{m}=$ multiplet, $\operatorname{comp}=$ composite of magnetically non-equivalent protons, $\mathrm{dd}=$ doublet of doublets, $\mathrm{td}=$ triplet of doublets; $\mathrm{dt}=\mathrm{doublet}$ of triplets), coupling constants (Hz), integration and assignment. ${ }^{13} \mathrm{C}-\mathrm{NMR}$ spectra were collected on Bruker instrument (125 MHz, Bruker Corporation) with complete proton decoupling. Chemical shifts are reported in ppm from the tetramethylsilane with the solvent resonance as internal standard $\left(\mathrm{CDCl}_{3}, \delta=77.0\right)$. High-resolution mass spectra (HRMS) were performed on a Bruker MicroTOF-ESI mass spectrometer (Bruker Corporation) with an ESI resource using CsI or LTQ ESI positive ion calibration solution as the standard. Enantioselectivities were determined by HPLC analysis at $25^{\circ} \mathrm{C}$ using an Agilent 1260 Infinity HPLC System (Agilent-Technologies, Santa Clara, CA, USA) equipped with an G1311B quaternary pump, G1315D diode array detector, G1329B auto-sampler, G1316A thermostated column compartment and G1170A valve drive. For instrument control and data processing, Agilent OpenLAB CDS ChemStation Edition (1200-series) for LC \& LC/MS Systems (Rev. C.01.07 [26]) software was used. Chiralpak OD-H (0.46 mm $\times$ $250 \mathrm{~mm}$ ) columns were obtained from Daicel Chiral Technologies (Chiral Technologies Inc., West Chester, PA, USA). Tetrahydrofuran, dichloromethane, chloroform, and toluene were purified using a JC Meyer solvent purification system. All other solvents were purified and dried using standard methods.

\subsection{Abbreviations}

EtOAc — ethyl acetate, THF—-tetrahydrofuran, $\mathrm{MeOH}$ - methanol, DCM-dichlorome thane, TEA — triethylamine, MeCN-acetonitrile, $i$ - $\mathrm{PrOH}$-2-propanol, TLC—-thin layer chromatography, TMS - tetramethylsilane (Purchased from Fisher Scientific, Waltham, MA, USA). 


\subsection{Materials}

$\mathbf{1 a}, \mathbf{2 b}$ and $\mathbf{5}[18,30,32-34]$, ligands [35,36] and sulfur ylides [22-25] were prepared by reported methods. All commercially available reagents were used without further purification unless otherwise noted. Preparation of racemic-3a was discussed in Figure 2. Compound 1a was prepared from known diazoketone (6) using TIPSOTf and $\mathrm{Et}_{3} \mathrm{~N}$ in DCM [18]. Compound 8 was made from known compound $\mathrm{N}, \mathrm{N}$-dimethyl-3-oxopentanamide $\mathbf{7}$ using p-ABSA in acetonitrile [35] as shown in Scheme 6.<smiles>CCC(=O)CC(=O)N(C)CCCNc1ccc(S(N)(=O)=O)cc1</smiles>

Scheme 6. Preparation of 2-Diazo-N,N-dimethyl-3-oxopentanamide (8).

3.4. General Procedure for Asymmetric Catalytic [3 + 1]-Cycloaddition to Prepare

(R)-4-Benzoyl-N,N-dimethyl-2-(triisopropylsiloxy)cyclobut-1-ene-1-Carboxamide (3a)

To an oven-dried sealable 2-dram vial equipped with a stir bar were added $\mathrm{CuOTf} \cdot \mathrm{Tol}_{1 / 2}$ (12.93 $\mathrm{mg} 0.05 \mathrm{mmol}, 5 \mathrm{~mol} \%$ ) and $\mathbf{L 1 7}(51.84 \mathrm{mg}, 0.06 \mathrm{mmol}, 6 \mathrm{mmol} \%)$. After the vial was evacuated and backfilled with $\mathrm{N}_{2}$ three times, dry DCM $(1.0 \mathrm{~mL})$ was added via a syringe, and the resulting solution was stirred at room temperature for $1 \mathrm{~h}$ before the sulfur ylide $2 \mathbf{b}$ (310.0 mg, $1.00 \mathrm{mmol}, 1.0$ equiv.) dissolved in dry DCM (0.5 mL) was added dropwise via a syringe. The reaction was stirred at room temperature for $5 \mathrm{~min}$, and a solution of 2-diazo- $N, N$-dimethyl-3-(triisopropylsiloxy)but-3-enamide (1a, $373.2 \mathrm{mg}, 1.20 \mathrm{mmol}$, 1.2 equiv.) in dry DCM $(1.0 \mathrm{~mL})$ was then added dropwise at $\mathrm{rt}$ for $1 \mathrm{~h}$. The reaction mixture was stirred at the same temperature for $16 \mathrm{~h}$, filtered through a short pad of silica gel and washed. Then the reaction solution was filtered through a short pad of Celite. The filtrate was concentrated, and the residue was purified by flash chromatography on silica gel using 10:3 hexanes:ethyl acetate as the eluent to afford ( $R$ )-4-benzoyl- $N, N$-dimethyl2-(triisopropylsiloxy)cyclobut-1-ene-1-carboxamide (3a) as a colorless liquid. 79\% yield, $315 \mathrm{mg}$, 60\% ee, HPLC conditions for determination of enantiomeric excess: Chiralpak OD$\mathrm{H}$ column, $254 \mathrm{~nm}$, hexanes $/ i-\mathrm{PrOH}=97: 3,1.1 \mathrm{~mL} / \mathrm{min}, \mathrm{t}_{\mathrm{r}}(1)=13.00 \mathrm{~min}, \mathrm{t}_{\mathrm{r}}(2)=14.35 \mathrm{~min}$; ${ }^{1} \mathrm{H}-\mathrm{NMR}\left(500 \mathrm{MHz}, \mathrm{CDCl}_{3}\right) \delta 8.12-8.09(\mathrm{~m}, 2 \mathrm{H}), 7.55(\mathrm{tt}, J=7.3,2.2 \mathrm{~Hz}, 1 \mathrm{H}), 7.50-7.45$ $(\mathrm{m}, 2 \mathrm{H}), 4.51(\mathrm{dd}, J=5.0,1.9 \mathrm{~Hz}, 1 \mathrm{H}), 3.23(\mathrm{~s}, 3 \mathrm{H}), 3.94(\mathrm{~s}, 3 \mathrm{H}), 2.88(\mathrm{dd}, J=13.3,5.0 \mathrm{~Hz}$, $1 \mathrm{H}), 2.77(\mathrm{dd}, J=13.3,1.9 \mathrm{~Hz}, 1 \mathrm{H}), 1.26-1.18(\mathrm{~m}, 3 \mathrm{H}), 1.15-1.08$ (comp, $18 \mathrm{H}) ;{ }^{13} \mathrm{C}-\mathrm{NMR}$ $\left(125 \mathrm{MHz}, \mathrm{CDCl}_{3}\right) \delta$ 200.6, 163.5, 147.9, 136.7, 132.9, 128.5, 128.4, 111.7, 38.8, 37.7, 36.1, 34.8, 17.6, 12.5 ppm; HRMS (ESI) $\mathrm{m} / z$ calcd for $\mathrm{C}_{23} \mathrm{H}_{35} \mathrm{NO}_{3} \mathrm{Si}:[\mathrm{M}+\mathrm{H}]^{+} 416.2459$; found: 416.2448 .

3.5. Preparation of 4-Benzoyl-N,N-Dimethyl-2-(triisopropylsiloxy)cyclobut-1-ene-1-carboxamide (Racemic 3a)

To an oven-dried sealable 2-dram vial equipped with a stir bar were added $\mathrm{CuOTf} \cdot \mathrm{Tol}_{1 / 2}$ ( $4.6 \mathrm{mg}, 0.018 \mathrm{mmol}, 5 \mathrm{~mol} \%$ ) and sulfur ylide $2 \mathbf{b}(91.1 \mathrm{mg}, 0.36 \mathrm{mmol}, 1.0$ equiv.). After the vial was evacuated and backfilled with $\mathrm{N}_{2}$ three times, dry DCM $(2.0 \mathrm{~mL})$ was added via a syringe; and the solution was stirred at room temperature for $5 \mathrm{~min}$ before 2-diazo$\mathrm{N}, \mathrm{N}$-dimethyl-3-(triisopropylsiloxy)but-3-enamide (1a, $127.1 \mathrm{mg}, 0.36 \mathrm{mmol}, 1.2$ equiv.) dissolved in dry DCM $(2.0 \mathrm{~mL})$ was added dropwise via a syringe for $1 \mathrm{~h}$. The reaction solution was stirred at room temperature for $16 \mathrm{~h}$ then filtered through a short pad of Celite and washed with DCM. The filtrate was concentrated, and the residue was purified by flash chromatography on silica gel using 10:3 hexanes:ethyl acetate as the eluent to 
afford the corresponding racemic [3 + 1]-cycloaddition product 4-benzoyl- $N, N$-dimethyl-2(triisopropylsiloxy)cyclobut-1-ene-1-carboxamide (Racemic 3a) as a colorless liquid (115 mg, 87\%). Enantiomer composition was determined by HPLC analysis [Daicel chiralpak OD-H, hexanes $/ i-\mathrm{PrOH}=97 / 3,1.0 \mathrm{~mL} / \mathrm{min}, \lambda=254 \mathrm{~nm}, \mathrm{t} 1=13.90 \mathrm{~min}, \mathrm{t} 2=15.69 \mathrm{~min}$.

\subsection{Preparation of 2-Diazo-N,N-dimethyl-3-(triisopropylsiloxy)but-3-enamide (1a)}

To a $100 \mathrm{~mL}$ oven-dried round bottom flask containing a magnetic stirring bar, commercially available 2-diazo- $N, N$-dimethyl-3-oxobutanamide (6, 1.0 equiv., $5.18 \mathrm{~g}, 33.41 \mathrm{mmol}$ ) and $\mathrm{Et}_{3} \mathrm{~N}$ (1.5 equiv., $\left.6.97 \mathrm{~mL}, 50.12 \mathrm{mmol}\right)$ in DCM $(100 \mathrm{~mL})$ were added TIPSOTf (1.1 equiv., $9.87 \mathrm{~mL}, 36.75 \mathrm{mmol}$ ) slowly at $0{ }^{\circ} \mathrm{C}$. After the reaction mixture was stirred for $30 \mathrm{~min}$, hexane $(150 \mathrm{~mL})$ was added, followed by saturated aqueous $\mathrm{NaHCO}_{3}$ solution $(40 \mathrm{~mL})$. The organic phase was separated and washed two more times with saturated aqueous $\mathrm{NaHCO}_{3}$ solution $(40 \mathrm{~mL} \times 2)$ then dried with anhydrous $\mathrm{Na}_{2} \mathrm{SO}_{4}$. After evaporating the solvents, the residue was then purified by flash chromatography $\left(\mathrm{SiO}_{2}\right.$ was treated with hexanes with $5 \% \mathrm{Et}_{3} \mathrm{~N}$ for 10 min before use, hexanes 100\% then 10:1 hexanes; ethyl acetate as the eluent) to afford $10.01 \mathrm{~g}(95 \%)$ of 2-diazo- $\mathrm{N}, \mathrm{N}$-dimethyl-3-(triisopropylsiloxy)but-3enamide (1a) as yellow color liquid; ${ }^{1} \mathrm{H}-\mathrm{NMR}\left(500 \mathrm{MHz}, \mathrm{CDCl}_{3}\right) \delta 4.45(\mathrm{~d}, J=2.2 \mathrm{~Hz}, 1 \mathrm{H})$, $4.27(\mathrm{~d}, J=2.2 \mathrm{~Hz}, 1 \mathrm{H}), 3.00(\mathrm{~s}, 6 \mathrm{H}), 1.31-1.21(\mathrm{~m}, 3 \mathrm{H}), 1.14-1.08$ (comp, 18H); ${ }^{13} \mathrm{C}-\mathrm{NMR}$ $\left(125 \mathrm{MHz}, \mathrm{CDCl}_{3}\right) \delta 165.0,143.8,89.6,37.4,17.7,17.4,12.6,12.3 \mathrm{ppm}$; HRMS (ESI) $\mathrm{m} / z$ calculated for $\mathrm{C}_{15} \mathrm{H}_{27} \mathrm{~N}_{3} \mathrm{O}_{2} \mathrm{Si}$ : $[\mathrm{M}+\mathrm{H}]^{+}$312.2102; found 312.2096.

3.7. General Procedure for Catalytic [3 + 1]-Cycloaddition Reaction of Sulfur Ylides (2b) with $\mathbf{1 b}$ or Cyclopropenecarboxamides (5)

3.7.1. General Procedure for Asymmetric Catalytic CuOTf-Catalyzed [3 + 1]-Cycloaddition Reactions to Prepare $Z-3 \mathbf{b}$ and $E-3 \mathbf{b}$ from $\mathbf{1 b}(Z: E=1: 3)$ or $\mathbf{1 b}(Z \mathbf{Z}: \mathbf{E}=\mathbf{2 5 : 1})$

To an oven-dried sealable 2-dram vial equipped with a stir bar were added $\mathrm{CuOTf} \cdot \mathrm{Tol}_{1 / 2}$ (2.6 mg, $0.010 \mathrm{mmol}, 5 \mathrm{~mol} \%$ ) and bisoxazoline ligand $\mathbf{L 1 4}(6.1 \mathrm{mg}, 0.012 \mathrm{mmol}, 6 \mathrm{~mol} \%$ ). After the vial was evacuated and backfilled with $\mathrm{N}_{2}$ three times, dry DCM $(1.0 \mathrm{~mL})$ was added via a syringe and the resulting solution was stirred at room temperature for $1 \mathrm{~h}$ before sulfur ylide $\mathbf{2 b}(60.8 \mathrm{mg}, 0.20 \mathrm{mmol}, 1.0$ equiv.) dissolved in dry DCM $(0.5 \mathrm{~mL})$ was added dropwise via a syringe. The reaction was stirred at room temperature for $5 \mathrm{~min}$ and then a solution of cyclopropenecarboxamide $1 \mathbf{b}(78.0 \mathrm{mg}, 0.24 \mathrm{mmol}, 1.2$ equiv.) in dry DCM $(1.0 \mathrm{~mL})$ was then added dropwise for $1 \mathrm{~h}$. The reaction mixture was stirred at the same temperature for $24 \mathrm{~h}$, filtered through a short pad of silica gel and washed with DCM. The filtrate was further concentrated and directly subjected to analysis by ${ }^{1} \mathrm{H}-\mathrm{NMR}$. After that, the residue was purified by flash chromatography on silica gel using 10:0 to 10:3 hexanes:ethyl acetate as the eluent to afford the expected [3+1]-cycloaddition product $Z-3 b, E-3 b$ and diene (4).

For $\mathbf{1 b}(Z: E-1 \mathbf{b}=1: 3)$ using Ligand L14, Ylide $\mathbf{2 b}$ at $\mathrm{rt}, 24 \mathrm{~h}$ : Scale $0.2 \mathrm{mmol}, \mathrm{dr} 6: 1$ $(Z-3 \mathbf{b}: E-3 \mathbf{b}), 47 \mathrm{mg}$ of $Z-3 \mathbf{b}$ as colorless liquid, $57 \%$ yield, $64 \%$ ee; $10 \%$ of $E-3 \mathbf{b}, 7 \%$ ee and $15 \mathrm{mg}(22 \%)$ of 4 as colorless liquid; HPLC conditions for determination of enantiomeric excess of Z-3b: Chiralpak OD-H column, $254 \mathrm{~nm}$, hexanes $/ i-\mathrm{PrOH}=97: 3,1.0 \mathrm{~mL} / \mathrm{min}$, $\operatorname{tr}($ minor $)=13.15 \mathrm{~min}, \operatorname{tr}$ (major) $=17.19 \mathrm{~min}$; HPLC conditions for determination of enantiomeric excess of $\boldsymbol{E}-3 \mathbf{b}$ : Chiralpak OD-H column, $254 \mathrm{~nm}$, hexanes $/ i-\mathrm{PrOH}=97: 3$, $1.0 \mathrm{~mL} / \mathrm{min}, \operatorname{tr}($ minor $)=11.31 \mathrm{~min}, \operatorname{tr}($ major $)=9.63 \mathrm{~min}$.

For 1b $(Z: E-1 b=25: 1)$ using Ligand L14, Ylide $\mathbf{2 b}$ at rt, 24 h: Scale $0.2 \mathrm{mmol}$, dr 9:1 $(Z-3 \mathbf{b}: E-3 \mathbf{b}), 56 \mathrm{mg}$ of $Z-3 \mathbf{b}$ as colorless liquid, $69 \%$ yield, $68 \%$ ee; $8 \%$ of $E-3 \mathbf{b}, 20 \%$ ee and $10 \mathrm{mg}(15 \%)$ of 4 as colorless liquid; HPLC conditions for determination of enantiomeric excess of Z-3b: Chiralpak OD-H column, $254 \mathrm{~nm}$, hexanes $/ i-\mathrm{PrOH}=97: 3,1.0 \mathrm{~mL} / \mathrm{min}$, $\operatorname{tr}($ minor $)=13.61 \mathrm{~min}$, tr (major) $=18.10 \mathrm{~min}$; HPLC conditions for determination of enantiomeric excess of $\boldsymbol{E}$-3b: Chiralpak OD-H column, $254 \mathrm{~nm}$, hexanes $/ i-\mathrm{PrOH}=97: 3$, $1.0 \mathrm{~mL} / \mathrm{min}, \operatorname{tr}($ minor $)=11.34 \mathrm{~min}, \operatorname{tr}($ major $)=9.61 \mathrm{~min}$. 
3.7.2. General Procedure for Asymmetric Catalytic [3 + 1]-Cycloaddition to Prepare Z-3b and $E-3 b$ from 5

To an oven-dried sealable 2 -dram vial equipped with a stir bar were added CuOTf $\cdot$ Tol $_{1 / 2}$ (2.6 mg, $0.010 \mathrm{mmol}, 5 \mathrm{~mol} \%$ ) and bisoxazoline ligand L14 (6.1 mg, $0.012 \mathrm{mmol}, 6 \mathrm{~mol} \%$ ). After the vial was evacuated and backfilled with $\mathrm{N}_{2}$ three times, dry DCM $(1.0 \mathrm{~mL})$ was added via a syringe and the resulting solution was stirred at room temperature for $1 \mathrm{~h}$ before sulfur ylide $2 \mathbf{b}$ (61 mg, $0.20 \mathrm{mmol}, 1.0$ equiv.) dissolved in dry DCM (0.5 mL) was added dropwise via a syringe for $1 \mathrm{~h}$. The reaction was stirred at room temperature for $5 \mathrm{~min}$ and then a solution of cyclopropenecarboxamide 5 (71 $\mathrm{mg}, 0.24 \mathrm{mmol}, 1.2$ equiv.) in dry DCM $(0.5 \mathrm{~mL})$ was then added dropwise. The reaction mixture was stirred at the same temperature for $24 \mathrm{~h}$, filtered through a short pad of silica gel and washed with hexanes/EtOAc $(1: 1,10 \mathrm{~mL})$. The filtrate was further concentrated and directly subjected to analysis by ${ }^{1} \mathrm{H}-\mathrm{NMR}$. After that, the residue was purified by flash chromatography on silica gel using 10:0 to 10:3 hexanes:ethyl acetate as the eluent to afford to afford the expected [3 + 1]-cycloaddition product $Z-3 b, E-3 b$ and diene (4).

For 5 using Ligand L14, Ylide $2 \mathbf{b}$ at rt, 24 h: Scale $0.2 \mathrm{mmol}$, dr 12:1 (Z-3b:E-3b), $56 \mathrm{mg}$ of $Z \mathbf{Z}-3 \mathbf{b}$ as colorless liquid, $67 \%$ yield, $71 \%$ ee; $5.5 \%$ of $\boldsymbol{E}-3 \mathbf{b}, 16 \%$ ee and $5.5 \mathrm{mg}$ $(8 \%)$ of 4 as colorless liquid; HPLC conditions for determination of enantiomeric excess of Z-3b: Chiralpak OD-H column, $254 \mathrm{~nm}$, hexanes $/ i-\mathrm{PrOH}=97: 3,1.0 \mathrm{~mL} / \mathrm{min}$, tr (minor $)=13.65 \mathrm{~min}, \operatorname{tr}$ (major) $=17.76 \mathrm{~min}$; HPLC conditions for determination of enantiomeric excess of $\boldsymbol{E}-\mathbf{3 b}$ : Chiralpak OD-H column, $254 \mathrm{~nm}$, hexanes $/ i-\mathrm{PrOH}=97: 3,1.1 \mathrm{~mL} / \mathrm{min}$, $\mathrm{tr}$ $($ minor $)=11.50 \mathrm{~min}, \operatorname{tr}($ major $)=9.74 \mathrm{~min}$.

(3R,4S)-4-Benzoyl-3-methyl-N,N-dimethyl-2-(triisopropylsiloxy)cyclobut-1-ene-1-carboxamide (Z3b): ${ }^{1} \mathrm{H}-\mathrm{NMR}\left(500 \mathrm{MHz}, \mathrm{CDCl}_{3}\right) \delta 7.94(\mathrm{~d}, J=7.5 \mathrm{~Hz}, 2 \mathrm{H}), 7.54(\mathrm{t}, J=7.5 \mathrm{~Hz}, 1 \mathrm{H}), 7.44(\mathrm{t}$, $J=7.5 \mathrm{~Hz}, 2 \mathrm{H}), 4.64(\mathrm{~d}, J=4.9 \mathrm{~Hz}, 1 \mathrm{H}), 3.39-3.33(\mathrm{~m}, 1 \mathrm{H}), 3.29(\mathrm{~s}, 3 \mathrm{H}), 2.97(\mathrm{~s}, 3 \mathrm{H}), 1.23-1.05$ (comp, 21H), $0.97(\mathrm{~d}, J=6.9 \mathrm{~Hz}, 3 \mathrm{H}) ;{ }^{13} \mathrm{C}-\mathrm{NMR}\left(125 \mathrm{MHz}, \mathrm{CDCl}_{3}\right) \delta 199.4,164.3,150.3$, 137.2, 132.9, 128.5, 128.2, 110.6, 44.5, 43.0, 37.9, 34.7, 17.5, 13.0, 12.6; HRMS (ESI) $m / z$ calcd for $\mathrm{C}_{24} \mathrm{H}_{37} \mathrm{NO}_{3} \mathrm{Si}:[\mathrm{M}+\mathrm{H}]^{+} 416.2615$; found: 416.2610 .

(3R,4R)-4-Benzoyl-3-methyl-N,N-dimethyl-2-(triisopropylsiloxy)cyclobut-1-ene-1-carboxamide $(\boldsymbol{E}$ 3b): ${ }^{1} \mathrm{H}-\mathrm{NMR}\left(500 \mathrm{MHz}, \mathrm{CDCl}_{3}\right) \delta 8.06(\mathrm{~d}, J=7.4 \mathrm{~Hz}, 2 \mathrm{H}), 7.58-7.54(\mathrm{~m}, 1 \mathrm{H}), 7.48(\mathrm{t}, J=7.4$ $\mathrm{Hz}, 2 \mathrm{H}), 4.01(\mathrm{~d}, J=1.4 \mathrm{~Hz}, 1 \mathrm{H}), 3.21$ (brs, 3H), 3.01-2.95 (m, 1H), 2.93 (brs, 3H), 1.42 (d, $J=7.1 \mathrm{~Hz}, 3 \mathrm{H}), 1.23-1.05$ (comp, 21H).

N,N-Dimethyl-3-triisopropylsiloxy-2,4-pentadienecarboxamide (4): ${ }^{1} \mathrm{H}-\mathrm{NMR}\left(500 \mathrm{MHz}, \mathrm{CDCl}_{3}\right)$ : $\delta 6.20(\mathrm{dd}, J=17.1,10.7 \mathrm{~Hz}, 1 \mathrm{H}), 5.64(\mathrm{dd}, J=17.1,1.2 \mathrm{~Hz}, 1 \mathrm{H}), 5.32(\mathrm{~s}, 1 \mathrm{H}), 5.24$ (dd, $J=10.7,1.2 \mathrm{~Hz}, 1 \mathrm{H}), 3.06(\mathrm{~s}, 3 \mathrm{H}), 2.97(\mathrm{~s}, 3 \mathrm{H}), 1.24-1.18$ (comp, 3H), 1.16-1.08 (comp, 18H); ${ }^{13} \mathrm{C}-\mathrm{NMR}\left(125 \mathrm{MHz}, \mathrm{CDCl}_{3}\right) \delta 167.3,153.3,135.3,117.0,37.9,34.6,17.9,13.5 ; \mathrm{HRMS}$ (ESI) $m / z$ calcd for $\mathrm{C}_{16} \mathrm{H}_{31} \mathrm{NO}_{2} \mathrm{Si}:[\mathrm{M}+\mathrm{H}]^{+}$298.2197; found: 298.2193 .

\subsection{Preparation of 2-Diazo-N,N-dimethyl-3-oxopentanamide (8)}

To a stirred solution of $N, N$-dimethyl-3-oxopentanamide [35] (7, 3.00 g, $21.0 \mathrm{mmol})$ and p-acetamidobenzenesulfonyl azide ( $p$-ABSA, $5.00 \mathrm{~g}, 21.0 \mathrm{mmol})$ in acetonitrile $(80 \mathrm{~mL}), \mathrm{Et}_{3} \mathrm{~N}$ $(8.75 \mathrm{~mL}, 63.0 \mathrm{mmol})$ was added dropwise at $0{ }^{\circ} \mathrm{C}$ over $3 \mathrm{~min}$. The reaction mixture was warmed to room temperature and stirred for $16 \mathrm{~h}$. Acetonitrile was then removed under reduced pressure, and the residue was redissolved in dichloromethane. The sulfonamide precipitate was filtered, and the filtrate was concentrated under reduced pressure. The residue was then purified by silica gel column chromatography using a 10:4 to 10:6 gradient of hexane/ethyl acetate $(v / v)$ as the eluent to afford $2.95 \mathrm{~g}(83 \%)$ of 2-diazo- $N, N$-dimethyl3-oxopentanamide (8) as yellow color liquid. ${ }^{1} \mathrm{H}-\mathrm{NMR}\left(500 \mathrm{MHz}, \mathrm{CDCl}_{3}\right) \delta 3.00(\mathrm{~s}, 6 \mathrm{H})$, $2.65(\mathrm{q}, J=7.3 \mathrm{~Hz}, 2 \mathrm{H}), 1.14(\mathrm{t}, J=7.3 \mathrm{~Hz}, 3 \mathrm{H}) ;{ }^{13} \mathrm{C}-\mathrm{NMR}\left(125 \mathrm{MHz}, \mathrm{CDCl}_{3}\right) \delta 192.7$, 161.3, 37.4, 32.4, 8.3 ppm; HRMS (ESI) $m / z$ calculated for $\mathrm{C}_{7} \mathrm{H}_{11} \mathrm{~N}_{3} \mathrm{O}_{2}$ : $[\mathrm{M}+\mathrm{H}]^{+} 170.0924$; found 170.0923 . 
3.9. Preparation of 2-Diazo-N,N-dimethyl-3-((triisopropylsiloxy)pent-3-enamide, $\mathbf{1 b}$ $(Z: E-1 b=1: 3)$

$\mathbf{1 b}(Z: E=1: 3)$ was prepared from 2-diazo- $N, N$-dimethyl-3-oxopentanamide (8) according to reported [18,32] procedure using TIPSOTf (1.1 equiv.), $\mathrm{Et}_{3} \mathrm{~N}$ (1.5 equiv.) and $\mathrm{LiCl}$ (1.0 equiv.). Its $Z / E$ ratio was determined by ${ }^{1} \mathrm{H}-\mathrm{NMR}$ spectroscopy and $10 \%$ formation of cyclopropene 5 was observed compared to total olefin $(\boldsymbol{E}+\boldsymbol{Z})$. For simplicity only ${ }^{1} \mathrm{H}-\mathrm{NMR}$ of $\boldsymbol{E}$ isomer was given here; yield $95 \% ;{ }^{1} \mathrm{H}-\mathrm{NMR}$ of $\boldsymbol{E}\left(500 \mathrm{MHz}, \mathrm{CDCl}_{3}\right) \delta 4.93(\mathrm{q}, J=7.1 \mathrm{~Hz}$, $1 \mathrm{H}), 2.99(\mathrm{~s}, 6 \mathrm{H}), 1.57(\mathrm{~d}, J=7.1 \mathrm{~Hz}, 3 \mathrm{H}), 1.32-1.02(\mathrm{~m}, 21 \mathrm{H})$; HRMS (ESI) $m / z$ calculated for $\mathrm{C}_{16} \mathrm{H}_{31} \mathrm{~N}_{3} \mathrm{O}_{2} \mathrm{Si}:[\mathrm{M}+\mathrm{H}]^{+} 326.2258$; found 326.2253 .

\subsection{Preparation of 2-Diazo-N,N-dimethyl-3-(triisopropylsiloxy)pent-3-enamide, $\mathbf{1 b}$ $(\mathbf{Z}: \mathbf{E}-\mathbf{1} \boldsymbol{b}=25: 1)$}

The reported [30] procedure was modified to make 2-diazo- $N, N$-dimethyl-3-((triisopro pylsiloxy)pent-3-enamide $(Z: E-1 b=25: 1)$. The title compound includes a small percent (5-10\%) of cyclopropenecarboxamide 5 because enoldiazoacetamide undergoes dinitrogen extrusion to form cyclopropenecarboxamide, even when stored at $0{ }^{\circ} \mathrm{C}$. Compound $\mathbf{1 b}$ $(\mathrm{Z}: E=25: 1)$ in common NMR solvents $\left(\mathrm{CDCl}_{3}, \mathrm{CD}_{2} \mathrm{Cl}_{2}, \mathrm{DMSO}_{\mathrm{d} 6}, \mathrm{CD}_{3} \mathrm{NO}_{2}\right.$ and hexanes) is converted (at $0{ }^{\circ} \mathrm{C}$ ) to the corresponding cyclopropene (5), but was found to be stable at $-20{ }^{\circ} \mathrm{C}$ and should be stored at $-20{ }^{\circ} \mathrm{C}$. At $0{ }^{\circ} \mathrm{C}$ and $\mathrm{rt}, 20 \%$ and $70 \%$, formation of 5 was observed after $6 \mathrm{~h}$ respectively.

To a $100-\mathrm{mL}$ oven-dried vial equipped with a magnetic stirring bar, 2 -diazo- $N, N$ dimethyl-3-oxopentanamide $(8,200 \mathrm{mg}, 1.18 \mathrm{mmol})$ was added, and the system was filled with nitrogen. THF $(30 \mathrm{~mL})$ was then added, and the reaction solution was cooled to $-78{ }^{\circ} \mathrm{C}$ (dry ice/acetone bath), LiHMDS (1.30 mL, 1.0 M in the hexanes) was introduced dropwise over $2 \mathrm{~min}$, followed by the addition of TIPSOTf $(0.315 \mathrm{~mL}, 1.18 \mathrm{mmol})$ at $-78^{\circ} \mathrm{C}$. The resulting solution was stirred at $-78{ }^{\circ} \mathrm{C}$ until the reaction was complete (monitored by TLC, about $5-15 \mathrm{~min}$ ). The reaction was quenched at $-78{ }^{\circ} \mathrm{C}$ with ice-cold brine, and solvent was removed at $15^{\circ} \mathrm{C}$ under reduced pressure, and the residue was directly purified by column chromatography on silica gel which was pre-treated with 5 vol.\% triethylamine/hexanes (eluent: pure hexanes then 10\% EtOAc in hexanes) to give the desired product 2-diazo- $N, N$-dimethyl-3-(triisopropylsiloxy)pent-3-enamide, $\mathbf{1 b}$ $(Z: E-1 \mathbf{b}=25: 1)$ as yellow liquid which was immediately stored $-20{ }^{\circ} \mathrm{C} .{ }^{1} \mathrm{H}-\mathrm{NMR}$ of $\mathbf{1 b}-\mathbf{Z}$ $\left(500 \mathrm{MHz}, \mathrm{CDCl}_{3}\right) \delta 5.00(\mathrm{q}, J=6.9 \mathrm{~Hz}, 1 \mathrm{H}, \mathrm{Z}-\mathrm{H}), 3.01\left(\mathrm{~s}, 6 \mathrm{H}, \mathrm{NCH}_{3}\right), 1.70(\mathrm{~d}, J=6.9$ $\left.\mathrm{Hz}, 3 \mathrm{H}, \mathrm{CH}_{3}\right), 1.32-1.02$ (m, 21H, TIPS); ${ }^{13} \mathrm{C}-\mathrm{NMR}$ of $\mathbf{1 b}-\mathbf{Z}$ including $5\left(125 \mathrm{MHz}, \mathrm{CDCl}_{3}\right)$ $\delta 160.7,142.5,79.6,37.1,34.6,34.5,31.5,25.8,25.2,22.6,20.3,17.7,17.4,17.4,14.1,12.3$, 12.0, 11.8 ppm; HRMS (ESI) $m / z$ calculated for $\mathrm{C}_{16} \mathrm{H}_{31} \mathrm{~N}_{3} \mathrm{O}_{2} \mathrm{Si}:[\mathrm{M}+\mathrm{H}]^{+} 326.2258$; found 326.2254 .

\subsection{Preparation of N,N,3-Trimethyl-2-(triisopropylsiloxy)cycloprop-1-ene-1-carboxamide (5)}

2-Diazo-N,N-dimethyl-3-(triisopropylsiloxy)pent-3-enamide, $\mathbf{1 b}(\mathbf{Z}: \mathbf{E}-\mathbf{1 b}=1: 3)$ (1.00 g, $3.17 \mathrm{mmol}$ ) at room temperature was added to a $20 \mathrm{~mL}$ oven dried vial containing a magnetic stirring bar and $10 \mathrm{~mL} \mathrm{CHCl}_{3}$, and then the vial was screwed close. The sealed reaction mixture was heated in oil bath at $50{ }^{\circ} \mathrm{C}$ for $2 \mathrm{~h}$, during this time the diazo compound was converted to the corresponding cyclopropene. The color of the solution changed from yellow to colorless. Solvent was removed under reduced pressure to afford $980 \mathrm{mg}$ (>99\%) of N,N,3-trimethyl-2-(triisopropylsiloxy)cycloprop-1-ene-1-carboxamide (5) was obtained as colorless liquid and was characterized directly without further purification. Compound 5 was also obtained heating $\mathbf{1 b}(\mathbf{Z}: \mathbf{E}-\mathbf{1 b}=25: 1)$ in $\mathrm{CHCl}_{3}$ at $50{ }^{\circ} \mathrm{C}$ for $1 \mathrm{~h} .{ }^{1} \mathrm{H}-\mathrm{NMR}(500 \mathrm{MHz}$, $\left.\mathrm{CDCl}_{3}\right) \delta 3.16(\mathrm{~s}, 3 \mathrm{H}), 2.99(\mathrm{~s}, 3 \mathrm{H}), 2.38(\mathrm{q}, J=4.9 \mathrm{~Hz}, 1 \mathrm{H}), 1.30(\mathrm{~d}, J=4.9 \mathrm{~Hz}, 3 \mathrm{H}), 1.36-1.24$ (comp, 3H), 115-1.10 (comp, 18H); ${ }^{13} \mathrm{C}-\mathrm{NMR}\left(125 \mathrm{MHz}, \mathrm{CDCl}_{3}\right) \delta 160.7,142.5,79.6,37.1$, $34.5,25.8,20.3,17.9,17.8,17.7,17.7,17.5,17.4,17.4,12.3,12.0$ ppm; HRMS (ESI) $\mathrm{m} / z$ calculated for $\mathrm{C}_{16} \mathrm{H}_{31} \mathrm{NO}_{2} \mathrm{Si}:[\mathrm{M}+\mathrm{H}]^{+}$298.2197; found 298.2193. 


\section{Conclusions}

The influence of ligands on stereocontrol with $\gamma$-methyl-substituted $\mathbf{1 b}$ is surprisingly diverse. Diastereoselectivity favoring the cis isomer ranges from 2:1 with SaBox ligand L1 (Table 2, entry 1) to $>20: 1$ with the tetramethylene SaBox ligand L14 (Table 2, entry 7) (the cis-4,5-diphenyl-Box template) providing the highest diastereocontrol. The highest enantioselectivity is also found with L14 (Table 2, entries 6, 7) which appears to be the optimum between smaller (L12, Table 2, entry 5) and larger (L16 and L17, Table 2, entries $8,9)$ attachments. Similarly, the cis-4,5-diphenyl-Box template of L14 (Table 2, entry 6) provides higher stereocontrol than the analogous indanyl-Box template of L11 (Table 2, entry 4). For [3+1]-cycloaddition with $N, N$-dimethyl-enoldiazoacetamide 1a ligand L14 (Table 1, entry 7) exhibited much lower enantioselectivity, $34 \%$ ee compared to $60 \%$ ee with L17 (Table 1, entry 10), demonstrating a significant dependence of enantioselectivity on the chiral ligand. However, enantioselctivity for formation of the trans donor-acceptor cyclobutene isomer $\boldsymbol{E}-\mathbf{3 b}$ was very low in comparison and exhibited no obvious means for improvement with the ligands that were employed. Attempted extension of this methodology to the $\gamma$-ethyl-substituted enoldiazoacetamide using the same copper catalyst with ligand L14 at room temperature gave low product yield, low diastereoselectivity (2:1 cis:trans) and low enantioselectivity, which further signaled the inherent complexity of stereocontrol in these reactions.

The competitive formation of diene $\mathbf{4}$ was another surprise in this transformation. Not previously observed from reactions with the corresponding enoldiazoacetates [18], this product was observed in variable amounts from all reactions catalyzed by copper(I) with Box or Sabox ligands. However, diene 4 (Scheme S2, Supplementary Materials) was not formed when the copper catalyzed reaction with ylide $\mathbf{2} \mathbf{b}$ was performed without ligand with either enoldiazoacetamide $\mathbf{Z}-\mathbf{1 b}$ or with donor-acceptor cyclopropenecarboxamide 5 , and neither the sulfur ylide nor the ligand alone caused diene formation in reactions performed over $24 \mathrm{~h}$. Since a $20 \%$ excess of ligand was used to ensure that unligated copper(I) was minimized, we thought that the diene might arise from the ligand, acting as a base, to effect elimination from the intermediate metallo-enol carbene. Indeed, using $2.4 \mathrm{~mol} \%$ triethylamine in place of the ligand resulted in diene formation $(29 \%$ yield, Scheme S3, Supplementary Materials). However, limiting the amount of excess ligand in the [3+1]-cycloaddition reaction to exactly 1:1 correspondence with the copper catalyst did not reduce the amount of diene 4 formation; but lowering the temperature to $-20{ }^{\circ} \mathrm{C}$ brought diene formation down to $2 \%$.

In summary, $\mathrm{Cu}(\mathrm{I})$ catalyzed asymmetric [ $3+1]$ cycloaddition of $\alpha$-benzoyl diphenylsulfur ylide $\mathbf{2 b}$ with 3 -methyl- or un-substituted cyclopropenecarboxamides gives access to the synthesis of donor-acceptor cyclobutenecarboxamides in good yield and moderate enantioselectivity. Unlike their corresponding enoldiazoacetate, the $\gamma$-methyl substituted amide gives a high preference for the cis diastereoisomer. Reactivity and stereoselectivity of the amide and ester are significantly different, and formation of diene $\mathbf{4}$ from amide $\mathbf{1 b}$ suggests an elimination pathway for the intermediate metallo-enolcarbene.

Supplementary Materials: The following are available online: Table S1. Complete Data for Optimization in Catalytic Asymmetric [3 + 1]-Cycloaddition Reactions of $\mathbf{1 a}$ with $\mathbf{2 a / 2} \mathbf{2}$. Table S2. Solvent screening of [3+1]-Cycloaddition Reaction of $\mathbf{1 a}$ with $\mathbf{2 b}$ using ligand $\mathbf{1 7}$. Table S3. Complete Data for Optimization in Catalytic Asymmetric [3 + 1]-Cycloaddition Reaction of donor acceptor cyclopropene $\mathbf{5}$ with $\mathbf{2 b}$. Optimization of Conditions of Diene (4) formation. Scheme S1. Solvent screening of [3 + 1]-Cycloaddition Reaction of $\mathbf{1 a}$ with $\mathbf{2} \mathbf{b}$ using ligand $\mathbf{1 7}$. Scheme S2. Reactants Not Involved in Diene (4) formation. Scheme S3. Optimization of Conditions of Diene (4) formation. ${ }^{1} \mathrm{H}-$ and ${ }^{13} \mathrm{C}-\mathrm{NMR}$ spectra of $\mathbf{1 a}, \mathbf{3} \mathbf{a}, \mathbf{Z}-\mathbf{3} \mathbf{b}, \mathbf{4}, \mathbf{5}, \mathbf{8},(\mathbf{Z}: \mathbf{E}-\mathbf{1} \mathbf{b}=1: 3)$ and $(\mathbf{Z}: \mathbf{E}-\mathbf{1} \mathbf{b}=\mathbf{2}=\mathbf{2 5}: \mathbf{1})$. Selected chiral HPLC spectra of 3a, Z3-b and Z-3b.

Author Contributions: Conceptualization, M.P.D.; methodology, S.J. and D.M.; validation, S.J.; formal analysis, S.J. investigation, S.J. and D.M.; writing—original draft preparation, M.P.D. and S.J. writing-review and editing, M.P.D. and S.J.; supervision, M.P.D.; project administration, 
M.P.D.; funding acquisition, M.P.D. All authors have read and agreed to the published version of the manuscript.

Funding: This research was funded by National Science Foundation, grant number CHE-1763168.

Institutional Review Board Statement: Not applicable.

Informed Consent Statement: Not applicable.

Data Availability Statement: Not applicable.

Acknowledgments: We acknowledge the U.S. National Science Foundation (CHE-1763168) for funding this research.

Conflicts of Interest: The authors declare no conflict of interest. The funders had no role in the design of the study, in the collection, analyses, or interpretation of data, in the writing of the manuscript, or in the decision to publish the results.

Sample Availability: Samples of the donor-acceptor cyclopropenes or cyclobutenes described in this manuscript are available from the authors.

\section{References}

1. Antonsen, S.; Østby, R.B.; Stenstrøm, Y. Chapter 1-Naturally Occurring Cyclobutanes: Their Biological Significance and Synthesis. Stud. Nat. Prod. Chem. 2018, 57, 1-40.

2. Dembitsky, V.M. Naturally occurring bioactive Cyclobutane-containing (CBC) alkaloids in fungi, fungal endophytes, and plants. Phytomedicine 2014, 21, 1559-1581. [CrossRef]

3. Dembitsky, V.M. Bioactive cyclobutane-containing alkaloids. J. Nat. Med. 2008, 62, 1-33. [CrossRef]

4. Namyslo, J.C.; Kaufmann, D.E. The Application of Cyclobutane Derivatives in Organic Synthesis. Chem. Rev. 2003, 103, 1485-1538. [CrossRef]

5. Lee-Ruff, E.; Mladenova, G. Enantiomerically Pure Cyclobutane Derivatives and Their Use in Organic Synthesis. Chem. Rev. 2003, 103, 1449-1484. [CrossRef]

6. Ha, S.; Lee, Y.; Kwak, Y.; Mishra, A.; Yu, E.; Ryou, B.; Park, C.-M. Alkyne-Alkene [2 + 2] cycloaddition based on visible light photocatalysis. Nat. Commun. 2020, 11, 1-12. [CrossRef]

7. Bai, Y.-B.; Luo, Z.; Wang, Y.; Gao, J.-M.; Zhang, L. Au-Catalyzed Intermolecular [2 + 2] Cycloadditions between Chloroalkynes and Unactivated Alkenes. J. Am. Chem. Soc. 2018, 140, 5860-5865. [CrossRef]

8. Ogoshi, S.; Kumar, R.; Tamai, E.; Ohnishi, A.; Nishimura, A.; Hoshimoto, Y.; Ohashi, M. Nickel-Catalyzed Enantioselective Synthesis of Cyclobutenes via [2 + 2] Cycloaddition of $\alpha, \beta$-Unsaturated Carbonyls with 1,3-Enynes. Synthesis 2016, 48, 2789-2794. [CrossRef]

9. Shen, L.; Zhao, K.; Doitomi, K.; Ganguly, R.; Li, Y.-X.; Shen, Z.-L.; Hirao, H.; Loh, T.-P. Lewis acid-catalyzed selective [2 + 2]-cycloaddition anddearomatizing cascade reaction of aryl alkynes with acrylates. J. Am. Chem. Soc. 2017, 139, 13570-13578. [CrossRef]

10. Yoon, T.P. Visible Light Photocatalysis: The Development of Photocatalytic Radical Ion Cycloadditions. ACS Catal. 2013, 3, 895-902. [CrossRef]

11. Sakai, K.; Kochi, T.; Kakiuchi, F. Rhodium-catalyzed intermolecular [2 + 2] cycloaddition of terminal alkynes with electrondeficient alkenes. Org. Lett. 2013, 15, 1024-1027. [CrossRef]

12. Nishimura, A.; Ohashi, M.; Ogoshi, S. Nickel-catalyzed intermolecular [2 + 2] cycloaddition of conjugated enynes with alkenes. J. Am. Chem. Soc. 2012, 134, 15692-15695. [CrossRef]

13. Fan, B.-M.; Li, X.-J.; Peng, F.-Z.; Zhang, H.-B.; Chan, A.S.C.; Shao, Z.-H. Ligand-controlled enantioselective [2 + 2] cycloaddition of oxabicyclic alkenes with terminal alkynes using chiraliridium catalyst. Org. Lett. 2010, 12, 304-306. [CrossRef]

14. Lopez-Carrillo, V.; Echavarren, A.M. ChemInform Abstract: Gold(I)-Catalyzed Intermolecular [2 + 2] Cycloaddition of Alkynes with Alkenes. J. Am. Chem. Soc. 2010, 41, 9292-9294. [CrossRef] [PubMed]

15. Treutwein, J.; Hilt, G. Cobalt-catalyzed [2 + 2] cycloaddition. Angew. Chem. Int. Ed. 2008, 47, 6811-6813. [CrossRef] [PubMed]

16. Xu, Y.; Conner, M.L.; Brown, M.K. Cyclobutane and Cyclobutene Synthesis: Catalytic Enantioselective [2 + 2] Cycloadditions. Angew. Chem. Int. Ed. 2015, 54, 11918-11928. [CrossRef] [PubMed]

17. Parsutkar, M.M.; Pagar, V.V.; Rajanbabu, T.V. Catalytic Enantioselective Synthesis of Cyclobutenes from Alkynes and Alkenyl Derivatives. J. Am. Chem. Soc. 2019, 141, 15367-15377. [CrossRef] [PubMed]

18. Deng, Y.; Massey, L.A.; Zavalij, P.; Doyle, M.P. Catalytic Asymmetric [3+1]-Cycloaddition Reaction of Ylides with Electrophilic Metallo-enolcarbene Intermediates. Angew. Chem. Int. Ed. 2017, 56, 7479-7483. [CrossRef] [PubMed]

19. Cheng, Q.Q.; Yedoyan, J.; Arman, H.; Doyle, M.P. Dirhodium(II)-Catalyzed Annulation of Enoldiazoacetamides with $\alpha$ Diazoketones: An Efficient and Highly Selective Approach to Fused and Bridged Ring System. Angew. Chem. Int. Ed. 2016, 55, 5573-5576. [CrossRef] [PubMed] 
20. Padwa, A.; Austin, D.J.; Hornbuckle, S.F.; Semones, M.A.; Doyle, M.P.; Protopopova, M.N. Control of Chemoselectivity in Catalytic Carbenoid Reactions. J. Am. Chem. Soc. 1992, 114, 1874-1876. [CrossRef]

21. Kaiser, D.; Klose, I.; Oost, R.; Neuhaus, J.; Maulide, N. Bond-Forming and -Breaking Reactions at Sulfur(IV): Sulfoxides, Sulfonium Salts, Sulfur Ylides, and Sulfinate Salts. Chem. Rev. 2019, 119, 8701-8780. [CrossRef] [PubMed]

22. Ratts, K.W.; Yao, A.N. Stable Sulfonium Ylids. J. Org. Chem. 1966, 31, 1185-1188. [CrossRef]

23. Seshadri, R.; Pegg, W.J.; Israel, M. Diethyl oxomalonate. An improved synthesis. J. Org. Chem. 1981, 46, 2596-2598. [CrossRef]

24. Nozaki, H.; Takaku, M.; Kondô, K. Stable sulphonium phenacylides: Isolation and reactions. Tetrahedron 1966, $22,2145-2152$. [CrossRef]

25. Kramer, S.; Skrydstrup, T. Gold-Catalyzed Carbene Transfer to Alkynes: Access to 2,4-Disubstituted Furans. Angew. Chem. Int. Ed. 2012, 51, 4681-4684. [CrossRef] [PubMed]

26. Shved, A.S.; Tabolin, A.A.; Novikov, R.A.; Nelyubina, Y.V.; Timofeev, V.P.; Ioffe, S.L. Six-Membered Cyclic Nitroso Acetals: Synthesis and Studies of the Nitrogen Inversion Process of N-Silyloxy-3,6-dihydro-2H-1,2-oxazines. Eur. J. Org. Chem. 2016, 2016, 5569-5578. [CrossRef]

27. Zhu, C.; Xu, G.; Sun, J. Gold-Catalyzed Formal [4+1]/[4+3] Cycloadditions of Diazo Esters with Triazines. Angew. Chem. Int. Ed. 2016, 55, 11867-11871. [CrossRef]

28. Nocquet, P.; Opatz, T. Total Synthesis of $( \pm)$-Scopolamine: Challenges of the Tropane Ring. Eur. J. Org. Chem. 2016, 2016, 1156-1164. [CrossRef]

29. Xu, X.; Wang, X.; Zavalij, P.Y.; Doyle, M.P. Straightforward Access to the [3.2.2] Nonatriene Structural Framework via Intramolecular Cyclopropenation/Buchner Reaction/Cope Rearrangement Cascade. Org. Lett. 2015, 17, 790-793. [CrossRef]

30. Dong, K.; Marichev, K.O.; Xu, X.; Doyle, M.P. High Stereocontrol in the Preparation of Silyl-Protected $\gamma$-Substituted Enoldiazoacetates. Synlett 2019, 30, 1457-1461. [CrossRef]

31. Dong, K.; Marichev, K.O.; Doyle, M.P. The Role of Donor-Acceptor Cyclopropenes in Metal Carbene Reactions. Conversion of E-Substituted Enoldiazoacetates to Z-Substituted Metallo-Enolcarbenes. Organometal 2019, 38, 4043-4050. [CrossRef]

32. Deng, Y.; Jing, C.; Doyle, M.P. Dinitrogen extrusion from enoldiazo compounds under thermal conditions: synthesis of donoracceptor cyclopropenes. Chem. Commun. 2015, 51, 12924-12927. [CrossRef]

33. Liu, Q.; Rovis, T. Enantio- and Diastereoselective Intermolecular Stetter Reaction of Glyoxamide and Alkylidene Ketoamides. Org. Lett. 2009, 11, 2856-2859. [CrossRef]

34. Ge, L.-S.; Wang, Z.-L.; An, X.-L.; Luo, X.; Deng, W.-P. Direct synthesis of polysubstituted 2-aminothiophenes by Cu(ii)-catalyzed addition/oxidative cyclization of alkynoates with thioamides. Org. Biomol. Chem. 2014, 12, 8473-8479. [CrossRef] [PubMed]

35. Nolin, A.; Ahn, R.W.; Kobayashi, Y.; Kennedy-Smith, J.J.; Toste, F.D. Enantioselective Reduction of Ketones and Imines Catalyzed by (CN-Box)ReV-Oxo Complexes. Chem. Eur. J. 2010, 16, 9555-9562. [CrossRef] [PubMed]

36. Qiao, J.-B.; Zhao, Y.-M.; Gu, P. Asymmetric Intramolecular Desymmetrization of meso- $\alpha, \alpha^{\prime}$-Diazido Alcohols with Aryldiazoacetates: Assembly of Chiral C3 Fragments with Three Continuous Stereocenters. Org. Lett. 2016, 18, 1984-1987. [CrossRef] [PubMed] 